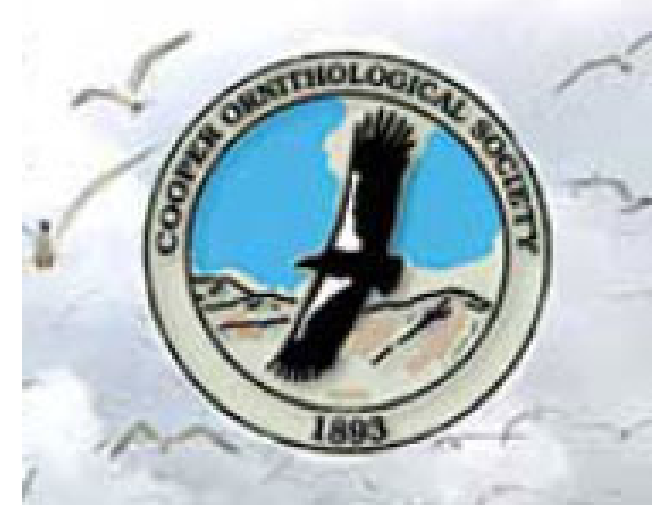

Mate Change and Reproductive Success in the Lesser Snow Goose Author(s): F. Cooke, M. A. Bousfield, A. Sadura

Reviewed work(s):

Source: The Condor, Vol. 83, No. 4 (Nov., 1981), pp. 322-327

Published by: University of California Press on behalf of the Cooper Ornithological Society

Stable URL: http://www.jstor.org/stable/1367500

Accessed: 24/04/2012 01:08

Your use of the JSTOR archive indicates your acceptance of the Terms \& Conditions of Use, available at http://www.jstor.org/page/info/about/policies/terms.jsp

JSTOR is a not-for-profit service that helps scholars, researchers, and students discover, use, and build upon a wide range of content in a trusted digital archive. We use information technology and tools to increase productivity and facilitate new forms of scholarship. For more information about JSTOR, please contact support@jstor.org. 


\title{
MATE CHANGE AND REPRODUCTIVE SUCCESS IN THE LESSER SNOW GOOSE
}

\author{
F. COOKE \\ M. A. BOUSFIELD
}

AND

A. SADURA

\begin{abstract}
The reproductive performance of Lesser Snow Geese (Anser caerulescens caerulescens) at La Pérouse Bay was examined in individuals retaining and in those changing their mate of the previous breeding season. Females retaining their mate had on average a slightly higher clutch size than those which did not. Other measures of reproductive success did not differ significantly between the two groups. The phenomenon of larger clutch size was not detectable in samples of older females. Females breeding for the second time, whether they changed mates or not, had a smaller clutch than did older birds, and clutch size was found to increase with age and/or experience, at least up to the third breeding attempt. We conclude that there is no causative relationship between mate loss and lowered clutch size. Nevertheless, females who breed for the first time are more likely to lose their mates and to have a lower-than-average clutch size as second-time breeders. In addition, first-time breeders were less co-ordinated in nest defense than more experienced birds.
\end{abstract}

Permanent monogamy is defined as the maintenance of a pair bond throughout the lifetime of the pair. Orians (1969) suggested that monogamy would evolve in those species where both sexes share equally in the care of the brood. Although monogamous mating systems are rare in mammals (see Eisenberg 1966 for a review), they predominate in the avian world. Lack (1968) estimated that about $90 \%$ of all bird species are monogamous.

Permanent monogamy is generally assumed to confer some selective advantage, yet in the field it is difficult to determine the nature of this advantage. Most of our understanding of the adaptive value of monogamy comes from studies of colonial seabirds. Coulson $(1966,1972)$ showed that the retention of the same mates allowed female Black-legged Kittiwakes (Rissa tridactyla) to breed earlier and produce larger clutches. Breeding success has been found to increase with the duration of the pair bond in several species, including Atlantic Gannets (Sula bassana; Nelson 1966), Manx Shearwaters (Puffinus puffinus; Brooke 1978) and Northern Fulmar (Fulmarus glacialis; Ollason and Dunnet 1978). Coulson (1966) showed that mate change in kittiwakes resulted in delayed clutch initiation and reduced reproductive success. A similar conclusion was reached by Mills (1973) in his study of Silver Gulls (Larus novaehollan- diae). Both kittiwakes (Coulson 1966, 1972) and fulmars (Ollason and Dunnet 1978) are more likely to change mates after reproductive failure.

The Anatidae constitute an anomaly in Orians' (1969) model of the evolution of monogamy. Most are precocial. Male involvement in parental care is limited in many species of ducks, yet monogamous bonding is quite common (Lack 1968). In geese, however, both sexes defend the brood, and male investment in reproduction may approach that of the female (Mineau 1978). Hence, it is not surprising that permanent monogamy is the predominant mating system among geese (Johnsgard 1975).

The Lesser Snow Goose (Anser caerulescens caerulescens) is an ideal species in which to investigate the long-term maintenance of a pair bond, since pairs remain together for many years, and "divorce" appears to be rare (Cooke and Sulzbach 1978). The pair bond is maintained throughout the year (Prevett and MacInnes 1980), juveniles often remaining with their parents over the winter and accompanying them to the breeding grounds in the following season (Cooch 1958, Abraham 1980).

In this paper, we examine the consequences of mate change by Lesser Snow Geese and examine the relationship between mate change, breeding experience and reproductive success. We hope that this 
investigation will shed some light on why permanent monogamy is the mating system of Lesser Snow Geese.

\section{METHODS}

The Snow Goose colony at La Pérouse Bay (LPB), Manitoba $\left(58^{\circ} \mathrm{N}, 93^{\circ} \mathrm{W}\right)$, has been under investigation since 1968. Each season the geese are captured during the flightless post-breeding period (late July) and each fitted with an aluminum Canadian Wildlife Service band and a colored plastic band indicating year of banding and age of the bird. With few exceptions, both members of a pair are banded together in the banding drives.

Since 1972 the color bands have been engraved with unique alphanumeric codes, which allow individual recognition of colony birds. About $40 \%$ of the $4,000+$ pairs at LPB can be identified in this manner.

Each season up to 2,500 nests are located on the colony and nest history information such as initiation date, hatch date, clutch size, egg loss, number hatched and gosling loss is collected. In addition, band information on attendant pairs is recorded, allowing us to identify individual pairs, and hence, to detect mate changes in subsequent seasons.

Pair formation occurs on the wintering grounds (Cooke et al. 1975). The widespread mixing of individuals on the wintering grounds often results in pair formation between individuals of different natal colonies. Females, along with their mates, return to their natal colony to breed. A male, on the other hand, will return to his natal colony only if his mate is also from that colony (Rockwell and Cooke 1977). Thus, data on mate change at LPB are restricted to females.

Information on mate change or retention comes from two sources. Each year adults captured for the first time are given a unique color band combination. Thereafter, pairs seen carrying that combination are assumed to have been paired in the banding drive of a previous summer. If, on the other hand, the female carries bands of that color but the male is unbanded, it is assumed that she has lost her mate of the previous summer. The second method, which is more precise, involves individually identified females and their mates. Individual alphanumerics on the colored leg bands are read, allowing between-year comparisons to be made. In addition, these birds are of known age.

Mated pairs were not identified prior to the hatching period. This study is, therefore, concerned only with those birds that were successful at least until the end of the incubation period. Direct evidence of remating among failed breeders is still lacking.

The behavior of mated pairs was monitored at hatch by estimating the distance $(\mathrm{m})$ of each bird from the nest while the observer was present. This "hatch distance" was compared for birds with the same mate in successive years, birds with a new mate, and two-yearold females (first-time breeders).

Statistical procedures follow Sokal and Rohlf (1969) and all comparisons are significant at $P<0.05$ unless otherwise stated.

\section{RESULTS}

\section{CLUTCH SIZE}

Clutch size is defined as the total number of eggs recorded in the nest (Finney 1975). In each year from 1972-1979, females who had retained their mate of the previous season had a greater average clutch size than those females with a new mate. While this difference was not significant in any year, a Wilcoxon rank-sum test suggests a trend of reduced clutch size among remated females $(P<0.05)$.

\section{HATCH DATES}

Since there is an inverse correlation between hatch date and clutch size (Finney 1975), clutch size differences may simply reflect differences in the timing of hatch. Mean hatch dates did not, however, differ significantly in any year analyzed, $1975(\mathrm{t}=$ $0.87, \mathrm{df}=123, \mathrm{NS}), 1976(\mathrm{t}=0.92, \mathrm{df}=174$, NS) or $1977(t=0.50, \mathrm{df}=203$, NS), between remated females and those retaining their mate of the previous season.

\section{GOSLING SURVIVAL}

The number of goslings leaving the nest was measured for both remated and samemate females. Sample sizes were smaller than those on which our clutch size estimates were based, because not all nests were visited after hatch. Remated and samemate birds did not differ significantly in the number of goslings leaving the nest in 1975 $(\mathrm{t}=0.68, \mathrm{df}=192, \mathrm{NS}), 1976(\mathrm{t}=0.70, \mathrm{df}=$ $192, \mathrm{NS})$ or in $1977(\mathrm{t}=1.30, \mathrm{df}=249, \mathrm{NS})$. In addition, production loss did not differ between the two classes of females. Finally, there was no indication that same-mate females had more goslings survive to the fledging period. This lack of difference may, however, reflect low sample size.

In summary, we found a trend towards reduced clutch sizes among remated females (as compared to same-mate females). No such trend was evident in our other estimates of reproductive fitness.

There are two non-exclusive hypotheses that may explain the difference between the two classes. It is conceivable that mate change results in a reduced clutch size in the year following the change. Alternatively, birds with a smaller clutch are perhaps more likely to change mates. In an attempt to distinguish between these hypotheses, we analyzed 163 individually identified pairs for which clutch size information had been obtained in two successive years. A bird in this sample must have bred at LPB at least three times: the year of banding, and the two years when clutch size information was obtained. In this sample of older birds, we found no difference in clutch size between remated and same-mate females, nor any differences in clutch sizes in the year prior to mate change. Since the sample size was relatively small (163 birds) we were forced to ignore inter-year differences in 
TABLE 1. Mean clutch size of remated females and those retaining mates, one year after banding.

\begin{tabular}{|c|c|c|c|c|c|}
\hline \multirow{2}{*}{$\begin{array}{c}\text { Year of } \\
\text { observa- } \\
\text { tion }\end{array}$} & \multicolumn{2}{|c|}{ Same mates } & \multicolumn{2}{|l|}{ Remates } & \multirow[b]{2}{*}{$t$ value } \\
\hline & $\bar{x} \pm \mathrm{SE}$ & $\mathrm{N}$ & $\bar{x} \pm \mathrm{SE}$ & $\mathrm{N}$ & \\
\hline 1974 & $5.00 \pm .30$ & 12 & $4.59 \pm .33$ & 17 & 1.02 \\
\hline 1975 & $4.53 \pm .18$ & 30 & $4.67 \pm .22$ & 12 & 0.21 \\
\hline 1976 & $4.88 \pm .23$ & 17 & $4.64 \pm .17$ & 14 & 0.82 \\
\hline 1977 & $4.28 \pm .22$ & 32 & $3.43 \pm .44$ & 14 & $1.85^{*}$ \\
\hline 1978 & $4.15 \pm .22$ & 34 & $3.75 \pm .25$ & 20 & 1.08 \\
\hline 1979 & $4.83 \pm .22$ & 18 & $4.00 \pm .37$ & 9 & $2.06^{*}$ \\
\hline Total & $4.52 \pm .09$ & 143 & $4.15 \pm .14$ & 86 & $2.22 *$ \\
\hline
\end{tabular}

clutch size. However, because the frequency of remated females did not differ markedly from year to year (1972-1979), this should not bias the result. Therefore, there is no evidence in support of either hypothesis. Presumably, the difference reflects age differences between the two classes, insofar as younger birds, which tend to have smaller clutches, may be more likely to change mates.

\section{AGE EFFECTS}

The LPB banding program has been in operation for 11 years and many of the females captured in a particular year have been banded previously. Thus, in the more recent years of the study, a large proportion of newly banded birds were first-time breeders when banded, and information collected in the following season reflects their second nesting attempt. Our previous analyses of clutch size did not attempt to distinguish age differences between individuals. Table 1 includes only those birds which had been banded in the year prior to observation. In this subsample the trend towards lower clutch size of remated birds is evident in all years except 1975, and in 1977 and 1979 the difference is significant. In Table 2 the mean clutch size of these birds is compared with that of known older birds,

TABLE 2. Mean clutch size in relation to breeding experience of remated females and those retaining their mates.

\begin{tabular}{|c|c|c|c|c|c|}
\hline \multirow{2}{*}{$\begin{array}{l}\text { Breeding } \\
\text { experi- } \\
\text { ence } \\
\text { (no. } \\
\text { breeding } \\
\text { seasons) }\end{array}$} & \multicolumn{2}{|c|}{ Same mates } & \multicolumn{2}{|l|}{ Remates } & \multirow[b]{2}{*}{$t$ value } \\
\hline & $\bar{x} \pm \mathrm{SE}$ & $\mathrm{N}$ & $\bar{x} \pm \mathrm{SE}$ & $\mathrm{N}$ & \\
\hline$\geqslant 2$ & $4.52 \pm .22$ & 143 & $4.15 \pm .14$ & 86 & $2.22 *$ \\
\hline$\geqslant 3$ & $4.47 \pm .21$ & 34 & $4.75 \pm .41$ & 8 & 0.58 \\
\hline$\geqslant 4$ & $4.57 \pm .18$ & 30 & $4.80 \pm .36$ & 10 & 0.62 \\
\hline$\geqslant 5$ & $5.00 \pm .24$ & 24 & $4.50 \pm .22$ & 6 & 1.59 \\
\hline$\geqslant 6$ & $4.39 \pm .25$ & 18 & $4.50 \pm .42$ & 8 & 0.15 \\
\hline
\end{tabular}

TABLE 3. Mean clutch size as affected by breeding experience, 1973-1979.

\begin{tabular}{|c|c|c|c|}
\hline & $\bar{x} \pm \mathrm{SE}$ & $\mathrm{N}$ & $t$ value \\
\hline $\begin{array}{l}\text { First-time breeders } \\
\text { (two-year-olds) }\end{array}$ & $3.46 \pm .06$ & 268 & \\
\hline $\begin{array}{l}\text { Second-time breeders } \\
\text { (three-year-olds observed } \\
\text { breeding also as two-year- } \\
\text { olds) }\end{array}$ & $3.97 \pm .19$ & & $2.67 * *$ \\
\hline $\begin{array}{l}\text { Third-time or greater } \\
\text { breeders }\end{array}$ & $4.58 \pm .06$ & 408 & \\
\hline
\end{tabular}

i.e. birds that have bred at least two years prior to the date when the data were collected. Only the sample with a large proportion of second-time breeders shows the reduced clutch size of remated birds.

Snow Geese generally enter the breeding population as two- or three-year-olds. Twoyear-olds lay smaller clutches than older birds (Prevett 1973, Finney and Cooke 1978). A similar trend, although to a lesser extent, was noted among three-year-olds (Finney and Cooke 1978).

To determine whether second-time breeders laid fewer eggs than more experienced birds, we compared individuals observed breeding as two-year-olds and again as three-year-olds, with birds that had bred at least three times at LPB, as well as with two-year-old first-time breeders (Table 3). Not only first-time, but also second-time breeders had significantly smaller clutches than older breeders. This suggests that the attainment of maximal clutch size requires at least two years of breeding experience. Within the sample of second-time breeders, clutch size did not differ significantly between females who had retained or changed mates. Sample sizes are low, with only six remates identified from among the $29 \mathrm{sec}-$ ond-time breeders. The sample of birds that showed a reduced clutch size among remated females comprised both second-time breeders and some older birds (Table 2). The smaller clutches among remated birds in the younger sample of birds (Table 2) may simply reflect the fact that second-time breeders lay fewer eggs, and are more likely to lose their mate after the first breeding attempt. If more remated than same-mate females are second-time breeders, this would explain their reduced clutch size.

There is some evidence to support the hypothesis that mate change is most common after the first breeding season. Firstly, the fraction of adult birds returning with new mates is much higher one year after 
TABLE 4. Mean distance in meters from the nest by members of the attendant pair at hatch.

\begin{tabular}{|c|c|c|c|c|c|c|c|}
\hline \multirow[b]{2}{*}{ Year sighted } & \multicolumn{2}{|c|}{ Same mates } & \multicolumn{2}{|c|}{ Remates } & \multirow[b]{2}{*}{$t$ value } & \multicolumn{2}{|c|}{$\begin{array}{c}\text { Two-year-old } \\
\text { females }\end{array}$} \\
\hline & $\bar{x} \pm \mathrm{SE}$ & $\mathrm{N}$ & $\bar{x} \pm \mathrm{SE}$ & $\mathrm{N}$ & & $\bar{x} \pm \mathrm{SE}$ & $\mathrm{N}$ \\
\hline \multicolumn{8}{|l|}{ Female } \\
\hline $\begin{array}{l}1976 \\
1977\end{array}$ & $\begin{array}{l}12 \pm 1.37 \\
22 \pm 2.25\end{array}$ & $\begin{array}{l}136 \\
166\end{array}$ & $\begin{array}{l}14 \pm 3.5 \\
22 \pm 6.1\end{array}$ & $\begin{array}{l}26 \\
27\end{array}$ & $\begin{array}{l}0.33 \\
0.02\end{array}$ & $\begin{array}{l}27 \pm 9.6 \\
31 \pm 5.5\end{array}$ & $\begin{array}{l}12 \\
21\end{array}$ \\
\hline \multicolumn{8}{|l|}{ Male } \\
\hline 1976 & $16 \pm 1.9$ & 136 & $31 \pm 6.7$ & 26 & $2.14^{*}$ & $59 \pm 12.1$ & 12 \\
\hline 1977 & $24 \pm 2.3$ & 166 & $47 \pm 7.8$ & 27 & $2.81^{*}$ & $51 \pm 7.8$ & 21 \\
\hline
\end{tabular}

banding than in subsequent years $(33.5 \%$ vs. $22 \%$; Cooke, unpublished data), a highly significant difference. Secondly, hunting mortality as measured by direct recovery rate of known first-time breeders in the following hunting season is $6.0 \%(19 / 317)$ as opposed to $4.4 \%(84 / 1,928)$ for older birds. Although this difference is not statistically significant, it suggests higher mortality among birds after their first breeding attempt. Thirdly, the probability of seeing a two-year-old female at a nest in the following year is $18.5 \%(20 / 108)$ whereas the probability of seeing an older female is $33.5 \%$ (118/352). This difference is highly significant and again suggests higher mortality in the season following first breeding.

\section{BEHAVIORAL DIFFERENCES}

Significant differences in behavior were observed between new pairs and pairs that had been together in at least the previous season (Tables 4 and 5). Table 5 also includes a comparison with two-year-old females (i.e., first-time breeders). These tables show that:

(1) there were no detectable differences in the mean hatch distances of remated females, and those who had retained their mate of the previous season;

(2) the males of newly formed pairs were much less attentive than males that had been paired with the same female for at least one season;

(3) the hatch distance of first-time breed- ing females was greater than that of older and more experienced females, and their mates behaved as attentively as or less attentively than the new mates of the remated female sample;

(4) pairs appeared to become more coordinated with the number of seasons spent together. This effect was evident only in 1976, when birds that had nested together for at least two years were more frequently the same distance from the nest. This usually meant that they were in close proximity to one another. Some pairs acted in unison while others appeared to behave independently. Remated pairs appeared to act in unison less frequently than pairs that had been together for at least two seasons.

\section{DISCUSSION}

In Lesser Snow Geese, unlike other species (see Coulson 1966, 1972, Davis 1976, Brooke 1978), there is no evidence that mate change results in a reduced clutch size. We attribute the observed decrease in clutch size of remated females to the fact that mate change occurs most often after the first breeding attempt. Thus, remated females include a high proportion of secondtime breeders. Because maximum egg production is not achieved until after the third breeding attempt, remated females will show a reduced clutch size relative to those that retain their mates of the previous season.

Mate loss (and subsequent remating) is

TABLE 5. Frequency of the sex closer to the nest at hatch.

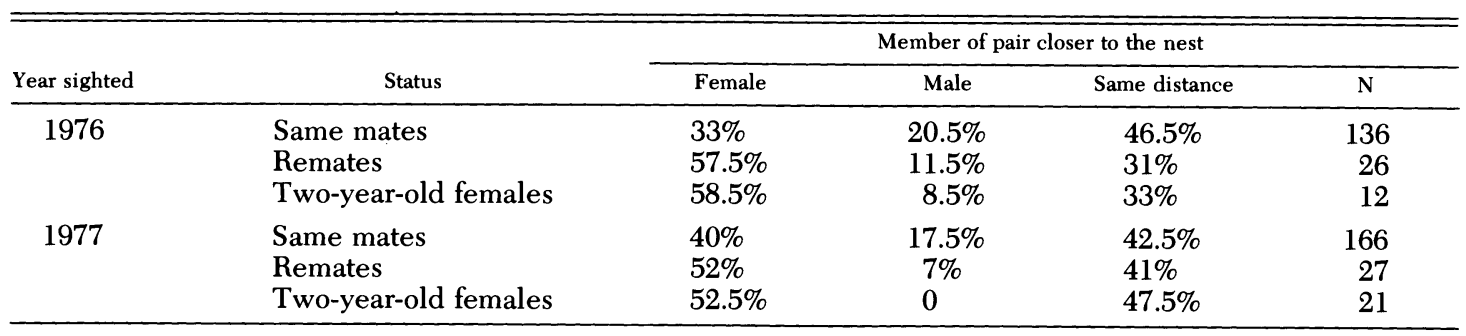


due to mortality or divorce. The similarity between estimates of adult mortality (Cooch 1958, Rienecker 1965, Sulzbach and Cooke 1979) and annual pair bond breakage (Cooke and Healey, unpubl.) in Lesser Snow Geese suggests a low incidence of divorce. However, at least five females at LPB are known to have changed mates even though their mates of the previous season were still alive. Clearly then, divorce occasionally occurs.

Previous studies of other species (e.g., Coulson 1966, 1972) have indicated that mate change is most common following a season of reduced reproductive success. If the past season was successful, individuals tend to remain together, or re-form pair bonds at the onset of the next breeding season. However, those individuals that change mates following an unsuccessful nesting attempt often increase their success in the following season (Ollason and Dunnet 1978).

Although we have no direct evidence of mate changing by unsuccessful pairs, several lines of evidence suggest that there is no difference in the frequency of mate change between successful and unsuccessful pairs. In arctic-nesting geese, conditions are often unsuitable for nesting, and large segments of a colony may fail to breed (Barry 1962). Such conditions prevailed at LPB in 1971 and 1977 , when $36-40 \%$ of the population failed to breed. However, the rate of pair bond breakage after these breeding seasons was no greater than in more successful seasons (Cooke, unpubl. data). Moreover, Prevett and MacInnes (1980) reported that pairs remained together even after the loss of an entire brood. After such reproductive failure, one might expect a change of mates to occur. Why, then, is it so rare?

The pair bond in geese is very strong. In semicaptive situations, enforced separation of members of a pair has led to continued searching for the mate (Lorenz 1959). Bonds persist even when there are no offspring to protect. Successful breeding adults remain with their offspring throughout the year and, as has been pointed out by several authors (Boyd 1953, Raveling 1970), larger families dominate smaller families and single birds. The dominance probably results in increased access to resources which, if limiting, would increase the chances of survival of an individual in a family group. Juveniles learn from their parents the best feeding and nesting locations and their traditions are passed on (Raveling 1970, Owen 1972, Lazarus and Inglis 1978, Cooke anc $\rightarrow$
Abraham 1980). The learning process can be expected to continue throughout the lifetime of the pair; hence pairs that remain together are better able to jointly defend resources.

Several researchers (Coulson and White 1958, Nelson 1966, Brooke 1978) have suggested that the coordination of parental care may be affected by experience. It is likely that this is related not only to the experience of individual members of the pair, but also to the pair itself. Nelson (1972) surmised that familiarity with a mate was important in determining the structure of the greeting ceremony, which, in turn, affected the timing of egg-laying. Coulson and White (1958) found first-time breeders un-coordinated in incubation of the clutch and feeding of the chicks. The increased efficiency of parental care probably also accounts for Ollason and Dunnet's (1978) observations that reproductive success in fulmars increases with the duration of the pair bond.

Increased coordination between pair members in incubating and feeding the young does not account for pair bonding in Lesser Snow Geese, since males do not incubate and the young are precocial. However, our estimates of hatch distance suggest that experienced birds are liable to be more attentive and coordinated in their defense of the nest. This is particularly important in Snow Geese, as nest failure due to desertion or predation accounts for much of the total production loss in the colony (unpubl. data). If individuals familiar with one another are more efficient in protecting the nest, there is an advantage to both sexes in maintaining the bond.

\section{ACKNOWLEDGMENTS}

To the many people who have braved the mosquitos and polar bears at the Queen's University Tundra Biology Station and to the Churchill Northern Studies Centre, we extend our thanks. Many of the data in this paper were analyzed by Marjorie Bousfield for a B.Sc. thesis at Queen's University. We also thank S. Findlay for helpful comments on earlier versions of this manuscript. This project is part of a general long-term population study of the La Pérouse Bay Snow Goose colony, which is funded by the Canadian Wildlife Service, Natural Sciences and Engineering Research Council of Canada, and the Mississippi and Central Flyway Councils.

\section{LITERATURE CITED}

ABrahaM, K. F. 1980. Breeding site selection of Lesser Snow Geese. Ph.D. diss., Queen's Univ., Kingston, Ontario.

BARRY, T. W. 1962. The effect of late seasons on Atlantic Brant reproduction. J. Wildl. Manage. 26:19-26.

BoyD, H. 1953. On encounters between wild White- 
fronted Geese in winter flocks. Behaviour 5:85129.

BROOKE, M. DE L. 1978. Some factors affecting the laying date, incubation and breeding success of the Manx Shearwater, Puffinus puffinus. J. Anim. Ecol. 47:961-976.

Cooch, F. G. 1958. The breeding biology and management of the Blue Goose. Ph.D. diss., Cornell Univ., Ithaca, NY.

CoOKe, F., AND K. F. Abraham. 1980. Habitat and locality selection in Lesser Snow Geese: the role of previous experience. Proc. XVII Int. Ornithol. Congr. (1978):998-1004.

CoOKE, F., AND D. S. SulzBaCH. 1978. Mortality, emigration and separation of mated Snow Geese. J. Wildl. Manage. 42:271-280.

Cooke, F., C. D. Macinnes, ANd J. P. Prevett. 1975. Gene flow between breeding populations of Lesser Snow Geese. Auk 92:493-510.

Coulson, J. C. 1966. The influence of pair-bond and age on the breeding biology of the Kittiwake gull Rissa tridactyla. J. Anim. Ecol. 35:269-279.

Coulson, J. C. 1972. The significance of the pairbond in the Kittiwake. Proc. XV Int. Ornithol. Congr. (1970): 424 .

Coulson, J. C., AND E. White. 1958. The effect of age on the breeding biology of the Kittiwake, Rissa tridactyla. Ibis 100:40-51.

DAvis, J. W. F. 1976. Breeding success and experience in the Arctic Skua, Stercorarius parasiticus (L.). J. Anim. Ecol. 45:531-536.

EISENBERG, J. F. 1966. The social organization of mammals. Handbuch der Zoologie 10:1-92. Walter de Gruyter, Berlin.

FINNEY, G. H. 1975. Reproductive strategies of the Lesser Snow Goose, Anser caerulescens caerulescens. Ph.D. diss., Queen's Univ., Kingston, Ontario.

FinNEY, G. H., AND F. CoOKE. 1978. Reproductive habits in the snow goose: the influence of female age. Condor 80:147-158.

JohnSGARD, P. 1975. The waterfowl of North America. Indiana Univ. Press, Bloomington.

LACK, D. 1968. Ecological adaptations for breeding birds. Methuen, London.

LAzARUS, J., AND I. R. INGLIS. 1978. Breeding behaviour of Pink-footed Goose parental care and vigilant behaviour during fledging period. Behaviour 65:62-87.

LoRENZ, K. 1959. The role of aggression in group formation, p. 181-252. In B. Schafner [ed.], Group processes: transactions of the fourth conference. Josiah Macy, Jr. Foundation, New York.
MILLS, J. A. 1973. The influence of age and pair-bond on the breeding biology of the Red-billed Gull, Larus novaehollandiae scopulinus. J. Anim. Ecol. 42:147-162.

MiNEAU, P. 1978. The breeding strategy of a male Snow Goose, Anser caerulescens caerulescens. M.Sc. thesis, Queen's Univ., Kingston, Ontario.

Nelson, J. B. 1966. The breeding biology of the Gannet, Sula bassana, on the Bass Rock, Scotland. Ibis 108:584-626.

Nelson, J. B. 1972. Evolution of the pair bond in the Sulidae. Proc. XV Int. Ornithol. Congr. (1970): 371-388.

Ollason, J. C., and G. H. Dunnet. 1978. Age, experience and other factors affecting the breeding success of the Fulmar, Fulmarus glacialis, in Orkney. J. Anim. Ecol. 47:961-976.

Oruans, G. H. 1969. On the evolution of mating systems in birds and mammals. Am. Nat. 103:589603.

OWEN, M. 1972. Some factors affecting food intake and selection in White-fronted Geese. J. Anim. Ecol. 41:79-92.

Prevet, J. P. 1973. Family behaviour and age dependent breeding biology of the Blue Goose, Anser caerulescens. Ph.D. diss., Univ. Western Ontario, London, Ontario.

Prevett, J. P., And C. D. MacInnes. 1980. Family and other social groups in snow geese. Wildlife Monogr. 71

Raveling, D. G. 1970. Dominance relationships and agonistic behaviour of Canada Geese in winter. Behaviour 37:291-319.

RIENECKER, W. C. 1965. A summary of band returns from Lesser Snow Geese (Chen hyperborea) of the Pacific Flyway. Calif. Dep. Fish Game 51:132146.

RoCKwell, R. F., AND F. CoOKe. 1977. Gene flow and local adaptation in a colonially nesting dimorphic bird: the Lesser Snow Goose (Anser caerulescens caerulescens). Am. Nat. 111:91-97.

SoKal, R. R., AND F. J. RoHLF. 1969. Biometry. Freeman, San Francisco.

SulzbaCh, D. S., AND F. CoOKE. 1979. Demographic parameters of a nesting colony of Lesser Snow Geese. J. Wildl. Manage. 42:437-441.

Department of Biology, Queen's University, Kingston, Ontario, Canada K7L 3N6. Address of second author: Department of Oceanography, Dalhousie University, Halifax, Nova Scotia, Canada B3H 4J1. Accepted for publication 13 November 1980. 